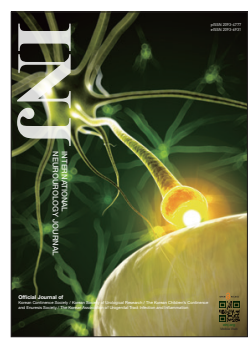

\title{
Pentoxifylline Alleviates Perinatal Hypoxic-Ischemia-Induced Short-term Memory Impairment by Suppressing Apoptosis in the Hippocampus of Rat Pups
}

\author{
Je Hoon Park ${ }^{1}$, Sung Eun Kim², Jun Jang Jin², Han Sung Choi³, Chang Ju Kim², Il Gyu Ko \\ ${ }^{1}$ Department of Surgery, International St. Mary's Hospital, College of Medicine, Catholic Kwandong University, Incheon, Korea \\ ${ }^{2}$ Department of Physiology, College of Medicine, Kyung Hee University, Seoul, Korea \\ ${ }^{3}$ Department of Emergency Medicine, College of Medicine, Kyung Hee University, Seoul, Korea
}

Purpose: Perinatal hypoxic-ischemic brain damage is a major cause of acute mortality and chronic neurologic morbidity in infants and children. We investigated the effects of pentoxifylline, a methylxanthine derivative and type-4 phosphodiesterase inhibitor, on short-term memory and apoptotic neuronal cell death in the hippocampus following perinatal hypoxic-ischemia in newborn rats.

Methods: We used a step-down avoidance task to evaluate short-term memory and 3'-5'-cyclic adenosine monophosphate (cAMP) assay to detect cAMP levels. We evaluated apoptosis using a terminal deoxynucleotidyl transferase-mediated dUTP nick end labeling (TUNEL) assay for evidence of DNA fragmentation, immunohistochemistry for caspase-3 levels, and western blot for Bcl-2 and Bax.

Results: Perinatal hypoxic-ischemic injury increased apoptotic cell death in the hippocampus, resulting in impaired shortterm memory with decreased cAMP levels. Pentoxifylline treatment improved short-term memory by suppressing apoptotic cell death in the hippocampus with elevated cAMP levels.

Conclusions: Pentoxifylline ameliorated perinatal hypoxic-ischemia in rat pups. This alleviating effect could be ascribed to the inhibition apoptosis due to increased cAMP production by pentoxifylline.

Keywords: Hypoxia-Ischemia; Pentoxifylline; Phosphodiesterase-4 Inhibitors; Memory; Cyclic AMP; Apoptosis

- Grant Support: This work was supported by the National Research Foundation of Korea Grant funded by the Korean Government (MEST) (NRF-2010-0022895).

- Research Ethics: All experiments were performed in accordance with the animal care guidelines of the National Institutes of Health and the Korean Academy of Medical Sciences.

- Conflict of Interest: No potential conflict of interest relevant to this article was reported.

\section{INTRODUCTION}

Perinatal hypoxic-ischemic brain damage is a major cause of acute mortality and chronic neurologic morbidity in infants and children. Perinatal hypoxic-ischemia is accompanied by neurodegeneration, including necrotic and apoptotic neuronal death [1,2]. Neuronal apoptosis is closely associated with brain damage induced by ischemia/reperfusion injury [3-5].

Apoptosis plays a crucial role in normal development and tissue homeostasis. Nevertheless, inappropriate or excessive apoptosis is implicated in several neurological disorders [3,6,7]. Terminal deoxynucleotidyl transferase-mediated dUTP nick
Corresponding author: Il Gyu Ko (iD http://orcid.org/0000-0003-2696-6869 Department of Physiology, College of Medicine, Kyung Hee University, 26 Kyungheedae-ro, Dongdaemun-gu, Seoul 02447, Korea

E-mail: rhdlfrb@hanmail.net / Tel: +82-2-961-0282 / Fax: +82-2-964-2195

Submitted: February 15, 2016 / Accepted after revision: March 17, 2016
This is an Open Access article distributed under the terms of the Creative Commons Attribution Non-Commercial License (http://creativecommons.org/licenses/by-nc/4.0/) which permits unrestricted non-commercial use, distribution, and reproduction in any medium, provided the original work is properly cited. 
end labeling (TUNEL) assay can detect DNA fragmentation, which is a characteristic of apoptotic cell death. An increase in the number of TUNEL-positive cells is reflective of apoptotic cell death $[3,6,8]$.

Another important characteristic of apoptosis is activation of caspases. Caspase- 3 is one of the most widely studied caspases, and plays a key-role in apoptosis. In ischemic animal models, caspase-3 activation is implicated in neuronal apoptosis $[3,5,9]$. In addition, the $\mathrm{Bcl}-2$ family of proteins also plays a pivotal role in the regulation of apoptosis. Bcl-2 proteins are classified into 2 groups: the antiapoptotic protein $\mathrm{Bcl}-2$ and the pro-apoptotic protein Bax [10]. The balance between pro-apoptotic and antiapoptotic Bcl-2 family members determines the mitochondrial response to apoptotic stimuli [11]. Enhancement of neuronal apoptosis by increases in Bax accompanied by decreases in Bcl2 contributes to central nervous system dysfunction $[6,12]$.

Pentoxifylline is a methylxanthine derivative and type-4 phosphodiesterase (PDE-4) inhibitor. It is widely used for the management of peripheral vascular diseases, particularly for intermittent claudication and cerebrovascular disease caused by impairment of microcirculation [13,14]. PDE-4 selective inhibitors have potential for therapeutic use [15]. They are highly specific for the hydrolysis of 3'-5'-cyclic adenosine monophosphate (cAMP), and are thus a key modulator of intracellular cAMP signaling pathways. cAMP plays critical roles in modulating brain functions, including neural circuit excitability, memory, and apoptosis $[16,17]$.

The protective effects of pentoxifylline on ischemic injuries in the lung, intestine, liver, and kidney have been demonstrated [18-20]. Many interventions have been investigated for the treatment of perinatal hypoxic-ischemic brain damage. However, no practical treatment method has been established for perinatal hypoxic-ischemic injury.

We investigated the effects of pentoxifylline on short-term memory and neuronal apoptosis in the hippocampus following hypoxic-ischemia in neonatal rats. Methodologies used to evaluate these effects included a step-down avoidance task, cAMP assay, TUNEL assay to detect DNA fragmentation, immunohistochemistry for caspase-3, and western-blot for Bcl-2 and Bax detection.

\section{MATERIALS AND METHODS}

\section{Experimental Animals}

Neonatal Sprague-Dawley rats (7 days old, $10-15 \mathrm{~g}$ in weight) were procured from a commercial breeder (Orient Co., Seoul, Korea). They were randomly divided into 4 groups ( $\mathrm{n}=10$ in each group): sham-operation group, perinatal hypoxic-ischemia-induced group, perinatal hypoxic-ischemia-induced and $50-\mathrm{mg} / \mathrm{kg}$ pentoxifylline-treated group, and perinatal hypoxicischemia-induced and $100-\mathrm{mg} / \mathrm{kg}$ pentoxifylline-treated group.

\section{Induction of Perinatal Hypoxic-Ischemia in Neonatal Rats}

Perinatal hypoxic-ischemia was induced as previous method [4]. Neonatal rats were anesthetized with isoflurane (2\% isoflurane in $30 \% \mathrm{O}_{2}$ and $70 \% \mathrm{~N}_{2}$; Vibac Laboratories, Carros, France). Following a neck incision, the right common carotid artery was permanently ligated with a 5-0 surgical silk suture. Subsequently, neonatal rats were placed in a chamber containing humidified $8 \% \mathrm{O}_{2}$ and $92 \% \mathrm{~N}_{2}$ for 90 minutes. For the neonatal rats in the sham-operation group, surgical incision was performed without ligation and without exposure to hypoxic conditions.

\section{Drug Treatment}

Neonatal rats in the pentoxifylline-treated groups received pentoxifylline (Sigma-Aldrich Chemical Co., St. Louis, MO, USA) intraperitoneally once a day for 7 consecutive days, starting one day after induction of perinatal hypoxic-ischemia. Neonatal rats in the sham-operation and hypoxic-ischemia-induced groups received an equal amount of saline intraperitoneally for the same duration.

\section{Step-Down Avoidance Task}

Latency in the step-down avoidance task was determined as described previously [5,21]. Rat pups (5 weeks old, 120-130 g in weight) were trained in a step-down avoidance task 28 days after induction of hypoxic-ischemia. Rat pups were placed on a $7 \times 25-\mathrm{cm}$ platform $2.5 \mathrm{~cm}$ high. The platform faced a $42 \times 25$ $\mathrm{cm}$ grid of parallel $0.1-\mathrm{cm}$ caliber stainless steel bars spaced 1 $\mathrm{cm}$ apart. During the training session, the animals received 0.5$\mathrm{mA}$ scrambled foot shocks for 2 seconds immediately upon stepping down. Two hours after training, the latency (s) was determined. The interval between the rat stepping down and placing all 4 paws on the grid was defined as the latency time. Latency over 180 seconds was counted as 180 seconds.

\section{Tissue Preparation}

Rat pups were sacrificed immediately after determining the latency in the step-down avoidance task. The animals were anesthetized using Zoletil $50(10 \mathrm{mg} / \mathrm{kg}$, intraperitoneally; Virbac 
Laboratories), transcardially perfused with $50 \mathrm{mM}$ phosphatebuffered saline, and then fixed with a freshly prepared solution of $4 \%$ paraformaldehyde in $100 \mathrm{mM}$ phosphate buffer ( $\mathrm{pH} 7.4$ ). Brains were then dissected, postfixed in the same fixative overnight, and transferred to $30 \%$ sucrose for cryoprotection. A freezing microtome (Leica, Nussloch, Germany) was used to generate $40-\mu \mathrm{m}$-thick coronal sections.

\section{Assay for Cyclic AMP}

The cAMP assay was performed using a commercially available cAMP competitive enzyme immunoassay kit (Sapphire Bioscience Pty. Ltd., Redfern, Australia) according to the manufacturer's instruction [5].

\section{TUNEL Staining}

TUNEL staining was performed using an In Situ Cell Death Detection Kit (Roche, Mannheim, Germany) according to the manufacturer's protocol $[5,8]$. The sections were postfixed in ethanol-acetic acid (2:1) and rinsed. The sections were then incubated with proteinase $\mathrm{K}(100 \mu \mathrm{g} / \mathrm{mL})$, rinsed, and incubated in $3 \% \mathrm{H}_{2} \mathrm{O}_{2}$, permeabilized with $0.5 \%$ Triton $\mathrm{X}-100$, rinsed again, and incubated in the TUNEL reaction mixture. The sections were then rinsed and visualized using Converter-POD with $0.03 \%$ 3, 3'-diaminobenzidine (DAB). Mayer's hematoxylin (DAKO, Glostrup, Denmark) was used as a counterstain, and the sections were mounted onto gelatin-coated slides.

\section{Caspase-3 Immunohistochemistry}

Caspase-3 immunohistochemistry was performed as described previously $[5,22]$. The sections were incubated overnight with mouse anti-caspase-3 antibody (1:500; Santa Cruz Biotechnology, Santa Cruz, CA, USA), followed by incubation with biotinylated mouse secondary antibody (1:200; Vector Laboratories, Burlingame, CA, USA) for another one hour. The secondary antibody was amplified with the Vector Elite ABC kit (1:100; Vector Laboratories). Antibody-biotin-avidin-peroxidase complexes were visualized using $0.03 \% \mathrm{DAB}$, and sections were mounted onto gelatin-coated slides.

\section{Western Blot Analysis}

Western blot analysis was performed as described previously [3,6]. Hippocampal tissues were homogenized with lysis buffer. Protein content was measured using a Bio-Rad colorimetric protein assay kit (Bio-Rad, Hercules, CA, USA). The protein mixture containing $40 \mu \mathrm{g}$ total protein was separated on sodi- um dodecyl sulfate-polyacrylamide gels and transferred onto a nitrocellulose membrane. Mouse actin antibody (1:2,000; Santa Cruz Biotechnology), mouse Bax antibody (1:1,000; Santa Cruz Biotechnology) and mouse Bcl-2 antibody (1:1,000; Santa Cruz Biotechnology) were used as primary antibodies. Horseradish peroxidase-conjugated antimouse antibodies for Bax and Bcl-2 (1:2,000; Amersham Pharmacia Biothech GmbH, Freiburg, Germany) were used as secondary antibodies. Bands were detected using an enhanced chemiluminescence detection kit (Santa Cruz Biotechnology).

\section{Data Analysis}

The number of TUNEL-positive and caspase-3-positive cells was expressed as number of cells per square millimeter in the CA1 region. To compare relative expression of proteins, we evaluated the detected bands densitometrically using Molecular Analyst ver. 1.4.1 (Bio-Rad). Statistical analysis was performed using one-way analysis of variance followed by Duncan post hoc test, and the results are expressed as mean \pm standard error of the mean. Significance was set at $\mathrm{P}<0.05$.

\section{RESULTS}

\section{Effect of Pentoxifylline on Short-term Memory}

Short-term memory was disrupted by perinatal hypoxic-ischemic injury $(\mathrm{P}<0.05)$, and pentoxifylline alleviated this memory impairment $(\mathrm{P}<0.05)$ (Fig. 1).

\section{Effect of Pentoxifylline on cAMP Levels in the Hippocampus}

Hippocampal cAMP levels were decreased by perinatal hypoxic-ischemic injury $(\mathrm{P}<0.05)$, and pentoxifylline increased the cAMP levels $(\mathrm{P}<0.05)$ (Fig. 2).

\section{Effect of Pentoxifylline on DNA Fragmentation in the Hippocampal CA1 Region}

DNA fragmentation in the CA1 region was increased by perinatal hypoxic-ischemic injury $(\mathrm{P}<0.05)$, and pentoxifylline suppressed this increase in DNA fragmentation $(\mathrm{P}<0.05)$ (Fig. 3).

\section{Effect of Pentoxifylline on Caspase-3 Expression in the Hippocampal CA1 Region}

Caspase- 3 expression in the CA1 region was enhanced by perinatal hypoxic-ischemic injury $(\mathrm{P}<0.05)$, and pentoxifylline suppressed this increase in caspase- 3 expression $(\mathrm{P}<0.05)$ (Fig. 4). 


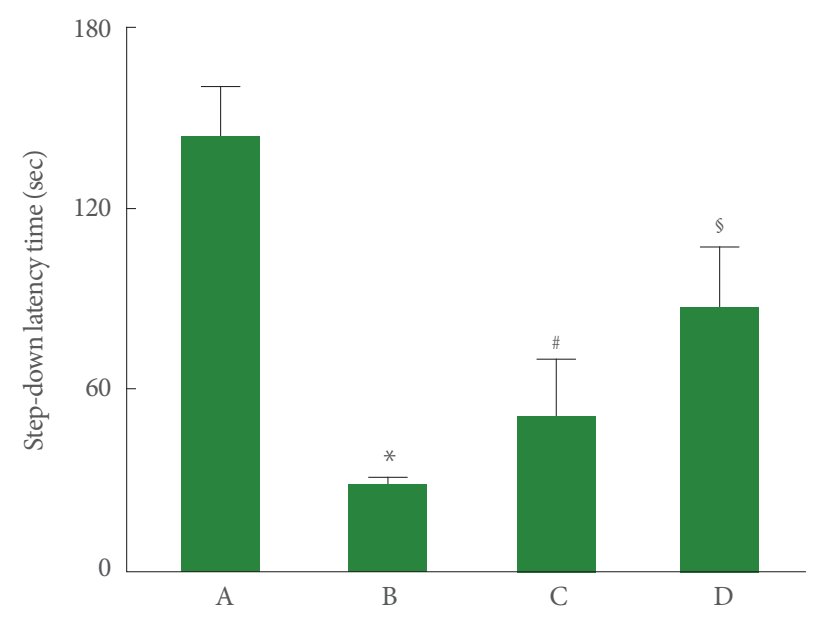

Fig. 1. Effect of pentoxifylline on latency in the step-down avoidance task. A, Sham-operation group; B, perinatal hypoxicischemia-induced group; $\mathrm{C}$, perinatal hypoxic-ischemia-induced and 50-mg/kg pentoxifylline-treated group; D, perinatal hypoxic-ischemia-induced and $100-\mathrm{mg} / \mathrm{kg}$ pentoxifylline-treated group. ${ }^{*} \mathrm{P}<0.05$ compared to the sham-operation group. ${ }^{\text {" }} \mathrm{P}<0.05$ compared to the perinatal hypoxic-ischemia-induced group. ${ }^{\mathrm{S}} \mathrm{P}<0.05$ compared to the perinatal hypoxic-ischemiainduced and $50-\mathrm{mg} / \mathrm{kg}$ pentoxifylline-treated group.

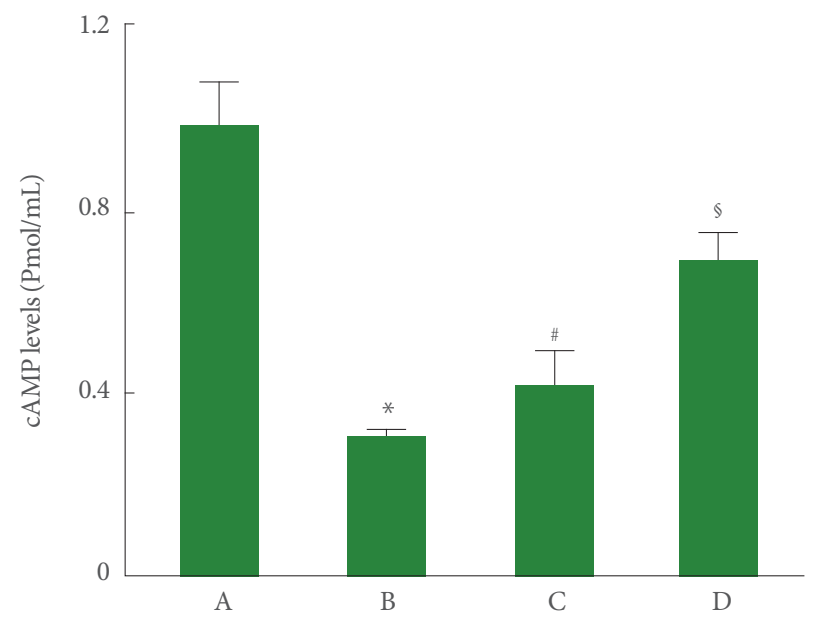

Fig. 2. Effect of pentoxifylline on $3^{\prime}-5^{\prime}$-cyclic adenosine monophosphate (cAMP) levels in the hippocampus. A, Sham-operation group; B, perinatal hypoxic-ischemia-induced group; $\mathrm{C}$, perinatal hypoxic-ischemia-induced and $50-\mathrm{mg} / \mathrm{kg}$ pentoxifylline-treated group; $\mathrm{D}$, perinatal hypoxic-ischemia-induced and $100-\mathrm{mg} / \mathrm{kg}$ pentoxifylline-treated group. ${ }^{*} \mathrm{P}<0.05$ compared to the sham-operation group. ${ }^{\#} \mathrm{P}<0.05$ compared to the perinatal hypoxic-ischemia-induced group. ${ }^{\varsigma} \mathrm{P}<0.05$ compared to the perinatal hypoxic-ischemia-induced and $50-\mathrm{mg} / \mathrm{kg}$ pentoxifylline-treated group.

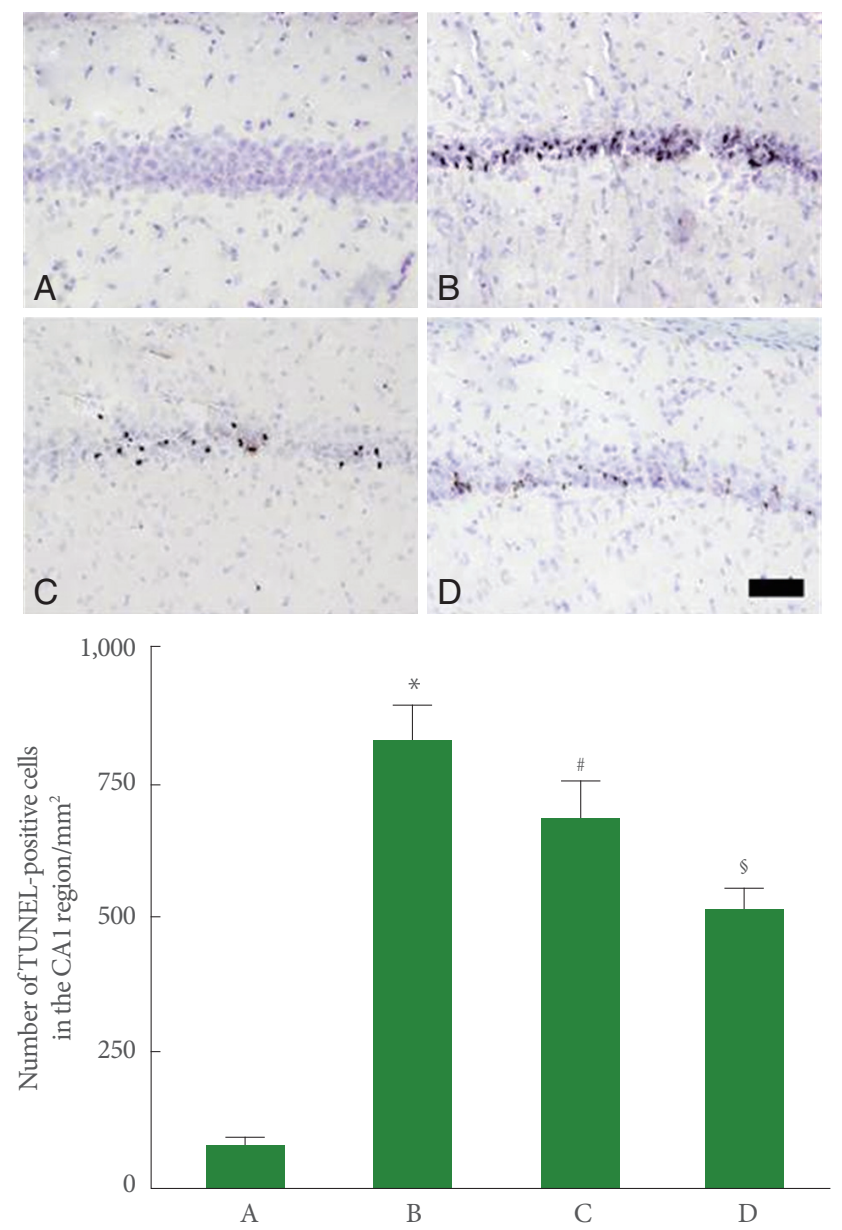

Fig. 3. Effect of pentoxifylline on DNA fragmentation in the hippocampal CA1 region. Upper panel: Photomicrographs of terminal deoxynucleotidyl transferase-mediated dUTP nick end labeling (TUNEL)-positive cells in the hippocampal CA1 region. A, Sham-operation group; B, perinatal hypoxic-ischemia-induced group; C, perinatal hypoxic-ischemia-induced and $50-\mathrm{mg} / \mathrm{kg}$ pentoxifylline-treated group; $\mathrm{D}$, perinatal hypoxic-ischemia-induced and $100-\mathrm{mg} / \mathrm{kg}$ pentoxifylline-treated group. Scale bar represents $400 \mu \mathrm{m}$. Lower panel: Number of TUNEL-positive cells in each group. ${ }^{*} \mathrm{P}<0.05$ compared to the sham-operation group. ${ }^{*} \mathrm{P}<0.05$ compared to the perinatal hypoxic-ischemia-induced group. ${ }^{\varsigma} \mathrm{P}<0.05$ compared to the perinatal hypoxic-ischemia-induced and $50-\mathrm{mg} / \mathrm{kg}$ pentoxifyllinetreated group.

\section{Effect of Pentoxifylline on Bax and Bcl-2 Expressions in the Hippocampus}

Perinatal hypoxic-ischemic injury increased Bax expression $(\mathrm{P}<0.05)$ and decreased Bcl-2 expression $(\mathrm{P}<0.05)$. Pentoxifylline suppressed Bax expression $(\mathrm{P}<0.05)$ and enhanced $\mathrm{Bcl}-2$ expression $(\mathrm{P}<0.05)$. As a result, the ratio of $\mathrm{Bax}$ to $\mathrm{Bcl}-2$ was 

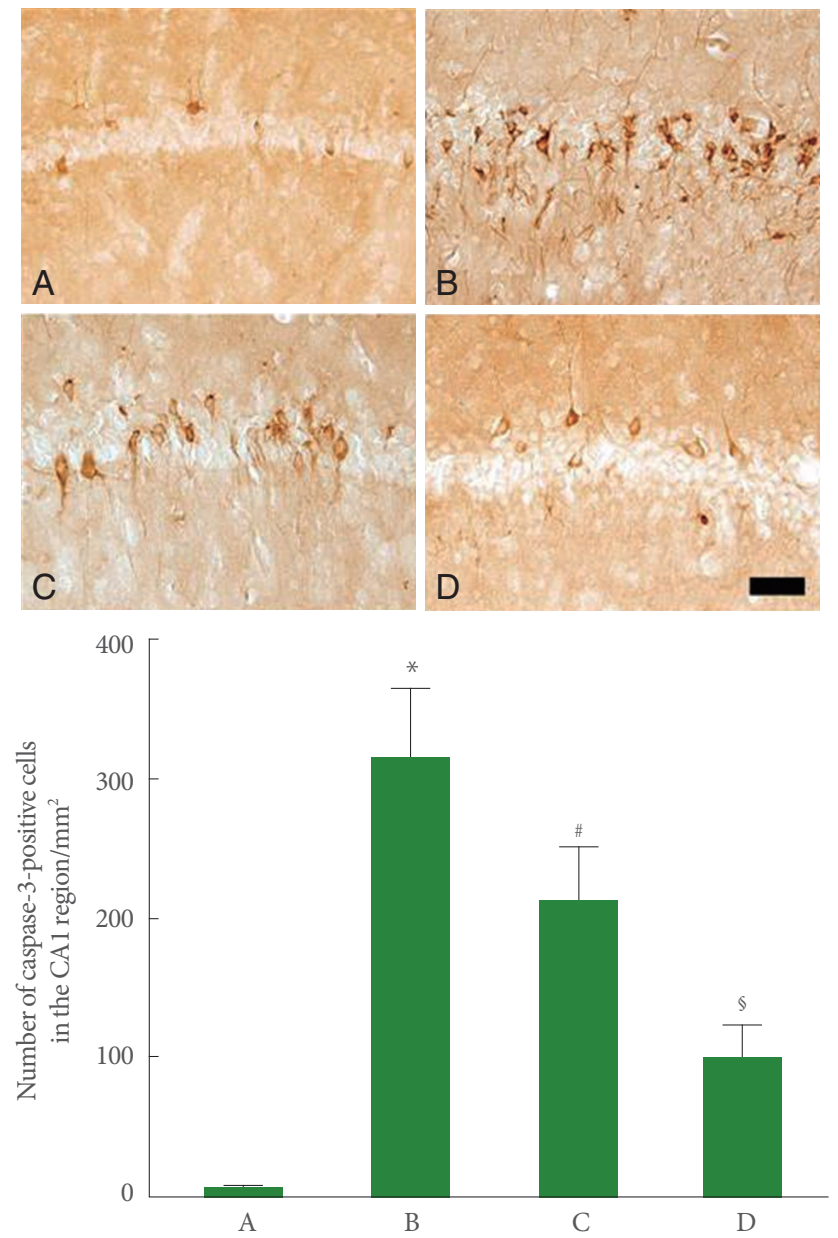

Fig. 4. Effect of pentoxifylline on caspase-3 expression in the hippocampal CA1 region. Upper panel: Photomicrographs of caspase-3-positive cells in the hippocampal CA1 region. A, Sham-operation group; B, perinatal hypoxic-ischemia-induced group; C, perinatal hypoxic-ischemia-induced and $50-\mathrm{mg} / \mathrm{kg}$ pentoxifylline-treated group; D, perinatal hypoxic-ischemia-induced and $100-\mathrm{mg} / \mathrm{kg}$ pentoxifylline-treated group. Scale bar represents $400 \mu \mathrm{m}$. Lower panel: Number of caspase-3-positive cells in each group. ${ }^{*} \mathrm{P}<0.05$ compared to the sham-operation group. ${ }^{*} \mathrm{P}<0.05$ compared to the perinatal hypoxic-ischemia-induced group. ${ }^{5} \mathrm{P}<0.05$ compared to the perinatal hypoxic-ischemia-induced and $50-\mathrm{mg} / \mathrm{kg}$ pentoxifylline-treated group.

increased by perinatal hypoxic-ischemic injury $(\mathrm{P}<0.05)$, and pentoxifylline suppressed this increase in the ratio of Bax to Bcl-2 $(\mathrm{P}<0.05)$ (Fig. 5).

\section{DISCUSSION}

Perinatal hypoxic-ischemic brain damage induces learning and memory deficits in rats $[23,24]$. Decreasing latency in the stepdown avoidance task represents impairment of short-term memory $[22,25]$. In this study, the latency in the step-down avoidance task was decreased by the induction of perinatal hypoxic-ischemia. These results reveal that perinatal hypoxicischemia disrupted short-term memory in the rat pups.

Enhanced apoptosis is implicated in several types of injuries $[5,26,27]$. In gerbils with ischemic injury, the number of TUNEL-positive and caspase-3-positive cells in the hippocampal CA1 region increased [25,28]. In this study, the number of TUNEL-positive and caspase-3-positive cells in the hippocampal CA1 region increased following perinatal hypoxic-ischemia. These results indicate that perinatal hypoxic-ischemia induced apoptotic neuronal cell death in the hippocampal CA1 region.

The Bcl-2 family of proteins, including Bcl-2 and Bcl-XL, play an important role in the regulation of apoptosis in the nervous system [29]. Bcl-2 inhibits apoptosis; however, Bcl-2 and Bcl-XL form heterodimers with the main pro-apoptotic member Bax, and inhibit its protective function [10]. Hence, the balance between Bax and Bcl-2 proteins is the crucial factor that regulates apoptosis [26,27]. Neonatal hypoxic-ischemic injury in the brain increased Bax levels with a decrease in Bcl-2 levels beginning 6 hours after the insult [30]. In this study, perinatal hypoxic-ischemic injury increased Bax expression and decreased Bcl-2 levels. Thus, the Bax to $\mathrm{Bcl}-2$ ratio increased, indicating that perinatal hypoxic-ischemic injury initiated apoptotic cell death in the hippocampus.

Eun et al. [31] showed that pentoxifylline reduced infarction size in the cerebral cortex following neonatal hypoxic-ischemic brain injury. Kalay et al. [32] reported that pentoxifylline suppressed caspase- 3 activity, and inhibited the expression of interleukin- $1 \beta$ and tumor necrosis factor- $\alpha$ mRNA in the left half of the brain after hypoxic-ischemic encephalopathy in neonatal rats.

Decrease in the number of TUNEL-positive and caspase3-positive cells in ischemic gerbils represents anti-apoptotic effects $[25,28]$. Decrease in the ratio of Bax to Bcl-2 also suggests inhibition of apoptosis in ischemic gerbils [25,28]. In this study, pentoxifylline suppressed the perinatal hypoxic-ischemia-induced increase in DNA fragmentation and caspase- 3 expression in the hippocampal CA1 region. Pentoxifylline also suppressed Bax expression and enhanced Bcl-2 expression, resulting in a decreased $\mathrm{Bax}$ to $\mathrm{Bcl}-2$ ratio. These results show that pentoxifylline inhibited perinatal hypoxic-ischemia-induced apoptosis in the hippocampus. 


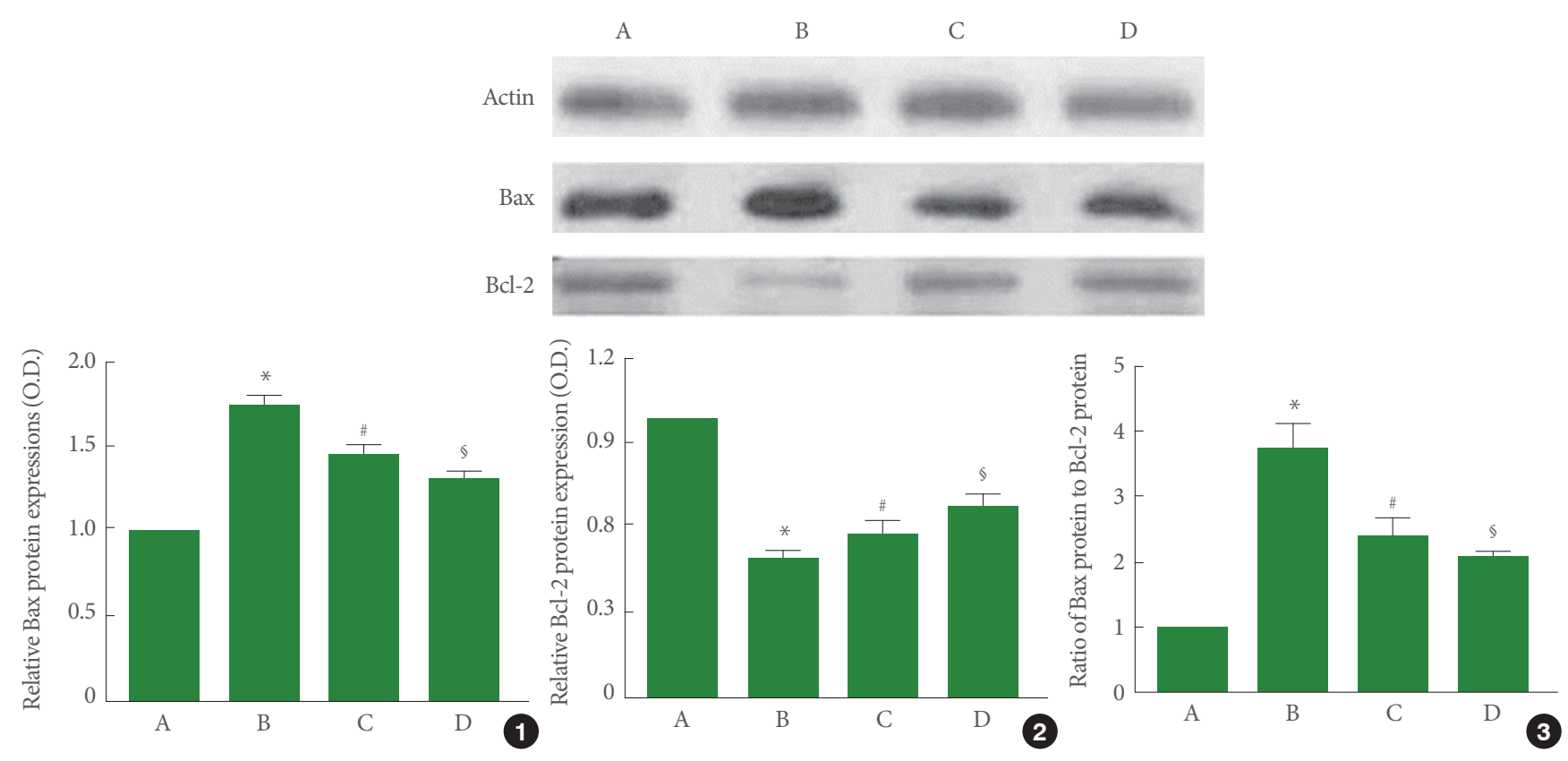

Fig. 5. Effect of pentoxifylline on Bax and Bcl-2 expression in the hippocampus. A, Sham-operation group; B, perinatal hypoxic-ischemia-induced group; $\mathrm{C}$, perinatal hypoxic-ischemia-induced and $50-\mathrm{mg} / \mathrm{kg}$ pentoxifylline-treated group; $\mathrm{D}$, perinatal hypoxic-ischemia-induced and 100-mg/kg pentoxifylline-treated group. Upper panel: Results of band detection using an enhanced chemiluminescence (ECL) detection kit. Lower panel: Relative expression of Bax and Bcl-2 in the hippocampus. (1) Relative expression of Bax. (2) Relative expression of Bcl-2. (3) Ratio of $\mathrm{Bax}$ to $\mathrm{Bcl}-2$. ${ }^{*} \mathrm{P}<0.05$ compared to the sham-operation group. ${ }^{*} \mathrm{P}<0.05$ compared to the perinatal hypoxic-ischemia-induced group. ${ }^{5} \mathrm{P}<0.05$ compared to the perinatal hypoxic-ischemia-induced and $50-\mathrm{mg} / \mathrm{kg}$ pentoxifylline-treated group.

During learning and memory, cAMP levels are elevated via a PDE-4-dependent process [15]. Inhibition of cAMP-dependent protein kinase A activation impairs conditioned fear memory [17]. In the present results, cAMP levels show a positive correlation with improvement of short-term memory and a negative correlation with apoptosis.

Our study demonstrates that pentoxifylline suppressed apoptosis in the hippocampus and improved short-term memory after perinatal hypoxic-ischemia. This alleviating effect on short-term memory impairment can be attributed to the inhibition of apoptosis due to increase in cAMP production by pentoxifylline.

\section{REFERENCES}

1. Ferriero DM. Neonatal brain injury. N Engl J Med 2004;351:198595.

2. Ness JM, Harvey CA, Strasser A, Bouillet P, Klocke BJ, Roth KA. Selective involvement of BH3-only Bcl-2 family members Bim and Bad in neonatal hypoxia-ischemia. Brain Res 2006;1099:150-9.
3. Cho YS, Shin MS, Ko IG, Kim SE, Kim CJ, Sung YH, et al. Ulinastatin inhibits cerebral ischemia-induced apoptosis in the hippocampus of gerbils. Mol Med Rep 2015;12:1796-802.

4. Choi JH, Kim TS, Park JK, Sim YJ, Kim K, Lee SJ. Short-term treadmill exercise preserves sensory-motor function through inhibiting apoptosis in the hippocampus of hypoxic ischemia injury rat pups. J Exerc Rehabil 2013;9:457-62.

5. Ko IG, Shin MS, Kim BK, Kim SE, Sung YH, Kim TS, et al. Tadalafil improves short-term memory by suppressing ischemiainduced apoptosis of hippocampal neuronal cells in gerbils. Pharmacol Biochem Behav 2009;91:629-35.

6. Ji ES, Kim YM, Shin MS, Kim CJ, Lee KS, Kim K, et al. Treadmill exercise enhances spatial learning ability through suppressing hippocampal apoptosis in Huntington's disease rats. J Exerc Rehabil 2015;11:133-9.

7. Lee MH, Kim H, Kim SS, Lee TH, Lim BV, Chang HK, et al. Treadmill exercise suppresses ischemia-induced increment in apoptosis and cell proliferation in hippocampal dentate gyrus of gerbils. Life Sci 2003;73:2455-65.

8. Lee TH, Kim K, Shin MS, Kim CJ, Lim BV. Treadmill exercise alle- 
viates chronic mild stress-induced depression in rats. J Exerc Rehabil 2015;11:303-10.

9. Benchoua A, Guegan C, Couriaud C, Hosseini H, Sampaio N, Morin $\mathrm{D}$, et al. Specific caspase pathways are activated in the two stages of cerebral infarction. J Neurosci 2001; 21:7127-34.

10. Kuwana T, Newmeyer DD. Bcl-2-family proteins and the role of mitochondria in apoptosis. Curr Opin Cell Biol 2003;15:691-9.

11. Upadhyay D, Panduri V, Ghio A, Kamp DW. Particulate matter induces alveolar epithelial cell DNA damage and apoptosis: role of free radicals and the mitochondria. Am J Respir Cell Mol Biol 2003;29:180-7.

12. Kuhn HG, Biebl M, Wilhelm D, Li M, Friedlander RM, Winkler J. Increased generation of granule cells in adult Bcl-2-overexpressing mice: a role for cell death during continued hippocampal neurogenesis. Eur J Neurosci 2005;22:1907-15.

13. Creager MA. Medical management of peripheral arterial disease. Cardiol Rev 2001;9:238-45.

14. Banfi C, Sironi L, De Simoni G, Gelosa P, Barcella S, Perego C, et al. Pentoxifylline prevents spontaneous brain ischemia in strokeprone rats. J Pharmacol Exp Ther 2004;310:890-5.

15. Houslay MD, Schafer P, Zhang KY. Keynote review: phosphodiesterase-4 as a therapeutic target. Drug Discov Today 2005;15:150319.

16. Lee D. Global and local missions of cAMP signaling in neural plasticity, learning, and memory. Front Pharmacol 2015;6:161.

17. Li Y, Li H, Liu X, Bao G, Tao Y, Wu Z, et al. Regulation of amygdalar PKA by beta-arrestin-2/phosphodiesterase- 4 complex is critical for fear conditioning. Proc Natl Acad Sci U S A 2009;22:918-23.

18. Iwamoto H, Kozaki K, Nakamura N, Hama K, Narumi K, Matsuno $\mathrm{N}$, et al. Beneficial effects of pentoxifylline and propentofylline on the warm ischemic injury of rat livers. Transplant Proc 2002;34: 2677-8.

19. Sener G, Akgun U, Satiroglu H, Topaloglu U, Keyer-Uysal M. The effect of pentoxifylline on intestinal ischemia/reperfusion injury. Fundam Clin Pharmacol 2001;15:19-22.

20. Thabut G, Brugiere O, Leseche G, Stern JB, Fradj K, Herve P, et al. Preventive effect of inhaled nitric oxide and pentoxifylline on ischemia/reperfusion injury after lung transplantation. Transplantation 2001;71:1295-300.

21. Kim K, Sung YH, Seo JH, Lee SW, Lim BV, Lee CY, et al. Effects of treadmill exercise-intensity on short-term memory in the rats born of the lipopolysaccharide-exposed maternal rats. J Exerc Rehabil 2015;11:296-302.

22. Kim SE, Ko IG, Kim BK, Shin MS, Cho S, Kim CJ, et al. Treadmill exercise prevents aging-induced failure of memory through an increase in neurogenesis and suppression of apoptosis in rat hippocampus. Exp Gerontol 2010;45:357-65.

23. Almli CR, Levy TJ, Han BH, Shah AR, Gidday JM, Holtzman DM. BDNF protects against spatial memory deficits following neonatal hypoxia-ischemia. Exp Neurol 2000;166:99-114.

24. Arteni NS, Salgueiro J, Torres I, Achaval M, Netto CA. Neonatal cerebral hypoxia-ischemia causes lateralized memory impairments in the adult rat. Brain Res 2003;973:171-8.

25. Kim M, Shin MS, Lee JM, Cho HS, Kim CJ, Kim YJ, et al. Inhibitory effects of isoquinoline alkaloid berberine on ischemia-induced apoptosis via activation of phosphoinositide 3-kinase/protein kinase B signaling pathway. Int Neurourol J 2014;18:115-25.

26. Han JH, Kim DO, Yi JW, Park SW, Kang WJ, Choi YK, et al. Dexmedetomidine, $\alpha 2$-adrenoceptor agonist, does not induce apoptosis in the brachial plexus of rats. Anim Cells Syst 2014;18:407-15.

27. Jeon JW, Lee JI, Shin HP, Cha JM, Joo KR, Kim SH, et al. Adenosine A2A-receptor agonist polydeoxyribonucleotide promotes gastric ulcer healing in Mongolian gerbils. Anim Cells Syst 2014;18: 399-406.

28. Seo TB, Kim TW, Shin MS, Ji ES, Cho HS, Lee JM, et al. Aerobic exercise alleviates ischemia-induced memory impairment by enhancing cell proliferation and suppressing neuronal apoptosis in hippocampus. Int Neurourol J 2014;18:187-97.

29. Akhtar RS, Ness JM, Roth KA. Bcl-2 family regulation of neuronal development and neurodegeneration. Biochim Biophys Acta 2004; 1644:189-203.

30. Carloni S, Buonocore G, Balduini W. Protective role of autophagy in neonatal hypoxia-ischemia induced brain injury. Neurobiol Dis 2008;32:329-39.

31. Eun BL, Liu XH, Barks JD. Pentoxifylline attenuates hypoxic-ischemic brain injury in immature rats. Pediatr Res 2000;47:73-8.

32. Kalay S, Oztekin O, Tezel G, Aldemir H, Sahin E, Koksoy S, et al. The effects of intraperitoneal pentoxifylline treatment in rat pups with hypoxic-ischemic encephalopathy. Pediatr Neurol 2013;49: 319-23. 